УАK 342

ББК 67.400

DOI 10.22394/1682-2358-2018-3-62-67

E.S Michurina, post-graduate student of the Constitutional and International Law Department, Povolzhsky Institute of Management named after P.A. Stolypin, Branch of the Russian Presidential Academy of National Economy and Public Administration

\section{CERTAIN PRINCIPLES \\ OF THE ECONOMIC FOUNDATIONS \\ OF THE \\ CONSTITUTIONAL SYSTEM OF THE RUSSIAN FEDERATION}

The content of the economic foundations of the constitutional system of the Russian Federation is considered. The problems of implementation and observance of the principles of economic fundamentals of the Russian constitutional system in practice are studied. The current legislation in this area and law enforcement practice are analyzed. Provisions to improve the mechanism for observing the principle of the unity of the economic space are proposed.

Key words and word-combinations: the basis of the constitutional system, competition, the prohibition of monopoly, the unity of the economic space.
E.C. Мичурина, аспирант кафедри конституиионного и международного права Поволжского института управления имени П.А. Стольпина - филиала Российской академии народного хозяйства и государственной службь при Президенте РФ (email: elizaveta_yakovleva@inbox.ru)

\section{НЕКОТОРЫЕ ПРИНЦИПЫ ЭКОНОМИЧЕСКИХ ОСНОВ КОНСТИТУЦИОННОГО СТРОЯ РОССИЙСКОЙ ФЕАЕРАЦИИ}

Аннотация. Рассматривается содержание экономических основ конституционного строя Российской Федерации. Исследуются проблемы реализации и соблюдения принципов экономических основ конституционного строя России на практике. Анализируется действующее законодательство в данной области и правоприменительная практика. Сформулированы рекомендации по совершенствованию механизма соблюдения принципа единства экономического пространства.

Ключевые слова и словосочетания: основы конституционного строя, конкуренция, запрет монополии, единство экономического пространства.

$\mathrm{O}$ сновой современных рыночных отношений, несомненно, явимось преобразование российского общества в политической и экономической сферах. Начало этих преобразований положила Конституция РФ, принятая в 1993 г. По справедиивому замечанию Н.И. Матузова, современные рыночные отношения в России стали складываться не потому, что были приняты определенные 
юридические нормы, касающиеся экономической жкизни, а потому, что они

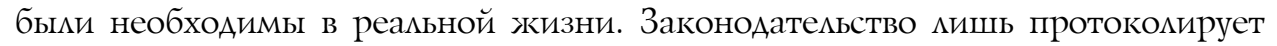
экономические потребности. Государство путем издания законов может в мучшем случае ускорять развитие существующих отношений, умавливать тенденции, Аавать простор Аля проявления позитивных начал [1, с. 208] .

С момента разработки нового Основного Закона страны начало развиваться отечественное законодательство, базирующееся на положениях демократического правового государства с развитым гражданским обществом, имеющего совершенно иные экономические основы. Соответствие реалиям современной жизни, совершенствование механизма государственного устройства с целью роста благосостояния общества, вкцючая кардинальную модернизацию всего внутреннего законодательства страны, - задачи, которые поставила перед собой новая Конституция Российской Федерации.

Коренные изменения в обществе повлекли за собой иные подходы к опредемению конституџионного строя Российской Федераџии и ее экономических основ. Перемены происходили в сложных исторических условиях формирования новой политической и экономической Аоктрины, становление которых прохоАило в тяжелый период политической, экономической и социальной жкизни общества в целом, что повлекло распаА Советского Союза. Сложность заключалась еще и в том, что экономическая сфера жкизни остро нуждалась в кардинацьном преобразовании. Это выражкалось в появившихся элементах экономических отношений в виде «теневой», полуофициальной экономики.

ОАнако Конституция РФ не констатирует конкретного положения об установлении рыночной экономики. Четкое определение этого строится прежке всего на иных понятиях, касающихся экономических прав и свобод [2, с. 124] . Так, в ст. 8 Конституции РФ содержатся понятия о единстве экономического пространства, свободном перемещении товаров, услуг и финансовых средств, поддержке конкуренции, свободе экономической деятельности, а также признании и защите частной, государственной, муниџипальной и иных форм собственности [3] .

Сокращение содержания закрепленных положений Конституции РФ дало возможность детализировать специацьное законодательство, а сама Конституция РФ получияа четкую характеристику в качестве фундаментального и базового источника права. Экономические основы, в свою очередь, находят отражение в главных положениях конституционного строя - важнейшей составцяющей конституционализма, так как экономика является одной из наиболее существенных сфер общественной жизни, влияющих на уровень социального бцагополучия граждан.

Вопросы и сравнения точек зрения научных деятелей о точности и разнообразии научных определений фундаментальных терминов конституционного строя, его основ и принципов в рамках конституционного права способствует вовцечению в более важную тему, а именно в проблему реацизации этих понятий в реальной жкизни, приобретая, таким образом, практическую значимость.

Принимая во внимание, что экономические основы конститущионного строя явцяются составной частью конституционного строя, считается возмож- 
ным дать определение этому понятию. По нашему мнению, экономические основы конституционного строя - это совокупность конституџионных принџипов и норм, направленных на регулирование экономических отношений, основанных на единстве экономического пространства, свободе экономической деятельности, признании и защите равным образом форм собственности с целью обеспечения стабильного экономического развития в интересах кичности и общества.

Раскрывая понятие экономических основ конститущионного строя России, отметим, что все решения государственной вцасти Аолжны быть соџиально ориентированы, направлены на воплощение экономических основ конституционного строя Российской Федераџии в повсеАневной жкини. Такой вывоА вытекает из признания на конституционном уровне России социальным госуАарством, предполагающего также и то, что экономические отношения строятся на социальном партнерстве между человеком и государством [4, с. 87] .

Аанная точка зрения нашиа отражение в ежегодном послании Президента РФ, адресованном Федеральному Собранию РФ: «Россия сегодня - одна из ведущих держав с мощным внешнеэкономическим и оборонным потенщиалом. Но с точки зрения важнейшей задачи обеспечения качества жкизни и благосостояния мюдей мы, конечно же, еще не Аостигли необходимого нам уровня. Но мы должны это сделать и сделаем это. <..> Чтобы идти впереА, Аинамично развиваться, мы должны расширить пространство свободы, причем во всех сферах, укреплять институты демократии, местного самоуправцения, структуры гражданского общества, судов, быть страной, открытой миру, новым идеям и инициативам» [5] .

Таким образом, разработка нового усовершенствованного законодательства ориентирована на обеспечение баланса интересов граждан, бизнеса и госуАарства [2, с. 123] . В научной митературе отмечается, что делается это с целью устранения измишнего неэффективного государственного регулирования хозяйственной деятельности [6, с. 3] , а следовательно, Аля стабильного развития страны как правового демократического государства и модернизаџии экономических основ конституционного строя Российской Федерации.

ОАним из примеров изменений законодательства в сторону упрощения реализации экономических основ явцяется расширение категории предпринимателей, относящихся к малому и среднему бизнесу, что позволяет им рассчитывать на подлержку государства [7]. В поправках к Федеральному закону от 24 июля 2007 г. № 209-Ф3 «О развитии малого и среАнего преАпринимательства в Российской Федерации» установлен максимальный размер выручки Аля преАставителей малого и среАнего бизнеса за преАшествующий год без учета НАС в два раза выше, чем ранее, и увеличен отчетный период о размере выручки для определения категории бизнеса (в течение трех $е т$ ). Это еще раз имюстрирует стремительный уход от тоталитарного режкима в экономической сфере и ориентирование государственного строя на рыночную экономику.

По вопросу проводимых реформ ведутся различные споры межау научными деятелями, практическими работниками, предприниматемями. В реацьной действительности выявцяются нарушения предписаний конституционных принципов о единстве экономического пространства в региональной бизнес- 
среде. Так, по данным Государственного совета РФ, в настоящее время усилимась тенденция экономического сепаратизма в субъектах РФ [8, с. 76]. Она выражается в действиях региональных вмастей, направленных на запрешение участникам рынка из других регионов вести коммерческую деятельность на территории своего субъекта. Такой характер действий был свойствен экономической политике России 1990-х годов. Аанная тенденџия влечет за собой угрозу экономической целостности и национальной безопасности государства $[8$, c. 49$]$.

ОАним из основных принципов экономических основ конституционного строя Российской Федераџии явмяется единство экономического пространства. ЕАинство рынка в экономическом пространстве подразумевает свободное перемещение товаров, услуг, денежных средств, а также свободу экономической деятельности на территории страны, подАержку конкуренции, запрет монополии. Следовательно, запретные действия региональных властей по отношению к участникам рынка из Аругих регионов явмяются не только тормозящим фактором Амя развития принщипов рыночной экономики, но и прямым нарушением предписаний Конститущии РФ.

Наиболее распространенные формы выражения протекционизма со стороны власти - установление устных и письменных запретов на ввоз товаров из Аругих регионов. Несмотря на очевидную направленность государственной политики на миберализаџию отношений государства с преАпринимательским сектором посреАством принятия соответствующих профильных нормативноправовых актов, роль органов муниџипальной власти весьма значительна. В силу административного ресурса действия органов местного самоуправления могут быть направлены, с одной стороны, на поддержку конкуренции и создание благоприятных условий Аля реализаџии экономических основ, а с Аругой стороны - на непосредственное вмешательство в конкурентный рынок.

В пример можно привести негативный опыт Саратовской области, выражающийся в маркетинговых дискриминационных условиях дмя продажи проАукщии. Так, Управление Федеральной антимонопомьной службы по Саратовской обкасти направило предписание министерству экономического развития Саратовской области в связи с имеющейся практикой мониторинга в торговых объектах алкогольной продукщии местного производства и размещения ее на полках магазинов «на уровне глаз» с целью увеличения объема продаж. Минэкономразвития области обязалось в дальнейшем исключать действия, направленные на создание преимущественных условий торговли дмя ООО «Первый Волжский винно-водочный комбинат», а также отозвало ранее отослонные письма в аАрес предприятий розничной торговли с запросом информаџии об объемах продажи водки местного производства $[8$, с. 80$]$.

Еще одной формой дискриминации производителей из других регионов выступают неправомерно вынесенные отказы в ввозе продукции. Например, в 2016 г. Ветеринарный комитет Волгоградской области необоснованно наложим запрет на ввоз свинины из Самарской области [9] .

В информационных документах Федеральной антимонопольной службы приводится множество примеров действий региональных властей, посягаю- 
щих на экономические основы конституционного строя в части принџипов единого экономического пространства, свободного перемещения товаров, усмуг и поддержку конкуренџии [10] .

Фундаментальная значимость конкуренции как составцяющей части экономических основ конституционного строя определена экономическим скцадом страны и подчеркивается положениями Конституции РФ. Нарушения в этой сфере наносят колоссальный ущерб экономике страны, что выдвигает обеспечение конституционных основ функщионирования свободного рынка и подАержку конкуренции на первостепенный уровень. По статистическим Аанным ФАС РФ в части нарушения антимонопольного законодательства органами вмасти, нарушениям органами местного самоуправления принадмежит абсомютное большинство - 98,8\%, когда как нарушения со стороны федерацьных органов вцасти составцяют мишь 1,2\% [11, с. 17].

По мнению В.В. Путина, высказанном на заседании Государственного совета по вопросу развития конкуренции, прошедшем в Кремле 5 апреля 2018 г., такая статистика свидетельствует о том, что в стране на уровне субъектов не придается Аолжного значения значимости конкуренџии и принџипу еАинства экономического пространства [12]. В целом Президент РФ резко негативно оценивает такой род явлений, как региональный протекционизм.

Необходимо добиться баланса межАу двумя позиџиями, при которых используются региональные мьготы Аля подАержкки предпринимателей и, как слеАствие, повышается занятость, доходы населения и пополняется местный бюджет, однако такие преференџии Аолжны быть доступны всем претендующим, без умышленного Аискриминационного ограничения предпринимателей из Аругих регионов.

Региональным органам вмасти следует понимать содержание одного из основных принщипов экономических основ конституционного строя Российской Федерации: единство экономического пространства явцяется ключевым элементом. При принятии управленческих решений целесообразно ориентироваться на выстраивание выгодной житемям региона экономики, особенно в части государственного и муниципацьного заказа как непосредственного элемента экономических отношений межАу институтами власти и предпринимательским сектором в качестве заказчика и исполнителя. Выбор высокоэффективных исполнителей на всем конкурентном рынке ведет к уменьшению расходов бюджетных среАств, повышению качеств продукции и в конечном итоге удовлетворению потребностей населения на высоком уровне. Аанная тема поднималась в рамках заседания Государственного совета РФ по вопросу развития конкуренџии [12] .

ОАнако отметим, что действия регионацьных властей не могут в полной мере обеспечить экономические основы конституционного строя, особенно в части подАержкки конкуренции. В соответствии с оАним из направцений Аеятельности Минэкономразвития РФ существует Аепартамент оценки регуАирования государственного воздействия. Аепартамент ОРВ проводит оџенку регулирующего воздействия проектов нормативных правовых актов и оџенку фактического воздействия нормативных правовых актов Аля выявцения положений, необоснованно затрудняющих ведение предпринимательской деятельности. Он объеАиняет экспертное сообщество, состоящее из преАставителей 
бизнеса разных уровней, научно-исследовательских сообществ, государственных институтов и региональных экспертов. Полагаем, что в рамках работы Аепартамента ОРВ необходимо ставить вопрос о том, не противоречит ми принимаемое на федеральном уровне законодательство нормам Конституции РФ в части возможности реализации экономических основ конституционного строя о подлержке конкуренщии. Необходимо провести экспертизу о влиянии принимаемых и действующих законов на соблюдение принщипов единства экономического пространства и свободного перемещения товаров, услуг и финансовых средств.

Таким образом, соблюдение положений экономических основ конституционного строя всей вертикалью власти и принятие соџиально ориентированных экономических решений - залог Аинамичного обновления экономики в сторону расширения рыночных отношений, а также повышения качества жизни гражАан России и создания благоприятных условий для малого и среАнего преАпринимательства как основной движущей силы экономического развития.

\section{Библиографический список}

1. Матузов Н.И., Малько А.В. Теория государства и права: учебник. М., 2004.

2. Мичурина E.C. Законодательное обеспечение экономических прав и основ: проблемный аспект // Парламентаризм в современном мире: теория и практика: материалы VII Международного конституционного форума, посвященного 10-летию юридического факультета Саратовского государственного университета имени Н.Г. Чернышевского (11 декабря 2015 г., Саратов). Саратов, 2016. Ч. 1.

3. Конституция Российской Федерации (с изм. от 21 июля 2014 г. № 11-ФКЗ) // СЗ РФ. 2014. № 31. Ст. 4398.

4. Конституционное право: учебник / Д.С. Велиева, М.В. Пресняков, С.Е. Чаннов [и др.]; под ред. Д.С. Велиевой. Саратов, 2017.

5. Послание Президента РФ Федеральному Собранию РФ от 1 марта 2018 г. Официальные сетевые ресурсы Президента России. URL: http://www.kremlin.ru/events/president/news/56957

6. Данилова И.В. Конституционные основы ограничения прав и свобод в экономической сфере (на примере лицензирования): автореф. дис. ... канд. юрид. наук. М., 2014.

7. О развитии малого и среднего предпринимательства в Российской Федерации: Федер. закон от 24 июля 2007 г. № 209-ФЗ (в ред. от 27 нояб. 2017 г.) // СЗ РФ. 2007. № 31. Ст. 4006. URL: http://www.pravo.gov.ru

8. Доклад Государственного совета Российской Федерации «О приоритетных направлениях деятельности субъектов Российской Федерации по содействию развитию конкуренции в Российской Федерации». М., 2018.

9. Решение Верховного Суда Российской Федерации от 7 июля 2017 г. по делу № A1246394/2016 «По заявлению Комитета ветеринарии Волгоградской области к Управлению Федеральной антимонопольной службы по Волгоградской области о признании недействительным предупреждения от 05.07.2016 № 03-7/4078 о прекращении действий (бездействия), которые содержат признаки нарушения антимонопольного законодательства» // Картотека арбитражных дел. URL: https://kad.arbitr.ru/

10. Федеральная антимонопольная служба России «Черная книга антиконкурентных региональных практик». М., 2017.

11. Доклад по правоприменительной практике, статистике типовых и массовых нарушений обязательных требований с разъяснением. Утв. ФАС России. М., 2017.

12. Стенографический отчет о заседании Государственного совета по вопросу развития конкуренции (5 апр. 2018 г.) Официальные сетевые ресурсы Президента России. URL: http:// www.kremlin.ru/events/president/news/57205 